IZA DP No. 1892

Oligopoly and Outsourcing

Subhayu Bandyopadhyay

Howard J. Wall

December 2005 


\title{
Oligopoly and Outsourcing
}

\author{
Subhayu Bandyopadhyay \\ West Virginia University \\ and IZA Bonn \\ Howard J. Wall \\ Federal Reserve Bank of St. Louis
}

Discussion Paper No. 1892

December 2005

\author{
IZA \\ P.O. Box 7240 \\ 53072 Bonn \\ Germany \\ Phone: +49-228-3894-0 \\ Fax: +49-228-3894-180 \\ Email: iza@iza.org
}

\begin{abstract}
Any opinions expressed here are those of the author(s) and not those of the institute. Research disseminated by IZA may include views on policy, but the institute itself takes no institutional policy positions.

The Institute for the Study of Labor (IZA) in Bonn is a local and virtual international research center and a place of communication between science, politics and business. IZA is an independent nonprofit company supported by Deutsche Post World Net. The center is associated with the University of Bonn and offers a stimulating research environment through its research networks, research support, and visitors and doctoral programs. IZA engages in (i) original and internationally competitive research in all fields of labor economics, (ii) development of policy concepts, and (iii) dissemination of research results and concepts to the interested public.
\end{abstract}

IZA Discussion Papers often represent preliminary work and are circulated to encourage discussion. Citation of such a paper should account for its provisional character. A revised version may be available directly from the author. 


\section{ABSTRACT}

\section{Oligopoly and Outsourcing*}

With outsourcing comes a perceived tension between the competitive pressures faced by domestic firms and the effect that outsourcing has on domestic workers. To address this tension, we present a general-equilibrium model with an oligopolistic export sector and a competitive import-competing sector. When there is a minimum wage, an outsourcing tax might be desirable and the usual profit-shifting objectives of an export subsidy are mitigated, perhaps completely, because it might lead to higher unemployment. Also, increased international competition has no affect on the level of outsourcing, but the direction of its effect on unemployment and national income depends on the relative factor intensities of the two sectors. Under wage flexibility, an outsourcing tax cannot be justified and the profitshifting motive is the same as in a model without outsourcing. Further, if export subsidies are not possible due to WTO regulations, it is optimal to subsidize rather than to tax outsourcing. Finally, the effect of increased foreign competition on welfare depends on the relative factor intensities of the two sectors.

JEL Classification: F1, F2, J3

Keywords: $\quad$ outsourcing, oligopoly, minimum wage

Corresponding author:

Subhayu Bandyopadhyay

Department of Economics

P.O. Box 6025

$B$ \& E Building, West Virginia University

Morgantown, WV 26506-6025

USA

Email: bandysub@mail.wvu.edu

\footnotetext{
* The views expressed are those of the authors and do not necessarily represent official positions of the Federal Reserve Bank of St. Louis or of the Federal Reserve System.
} 


\section{Introduction}

Outsourcing has become the focus of many recent discussions of policies governing international commerce. In the United States, for example, there is much concern that, while outsourcing may give an edge to US firms in terms of their global competitiveness, its effect on welfare is ambiguous because it hurts US labor. A dominant component of outsourcing is in labor services that can be directly used from foreign locations through advances in telecommunication. For example, Bhagwati, Panagariya, and Srinivasan (2004) point out that, unlike in the 1980s when outsourcing was principally viewed as fragmentation of the production process, the current pattern of outsourcing involves "long-distance" purchase of services from abroad. One such example are call centers that support bank credit cards. The person who answers your questions as a customer service representative can easily be located in Bangalore in India rather than in South Dakota in the US. In this sense, US and foreign labor are close substitutes in the production of many of the goods and services that are traded in the current marketplace.

In this context, US labor-market policies have a direct impact on US competitiveness, income distribution, and national welfare. Also, US policies that might help enhance the strategic position of US firms (à la Brander and Spencer, 1985) will have effects on the labor market. To address these issues, we consider a two-sector model with an oligopolistic export sector and an import-competing competitive sector. The model includes three types of labor: domestic skilled labor, domestic unskilled labor, and foreign unskilled labor. So that the model focuses on the tradeoff between global competitiveness and labor, we allow the oligopolistic sector to outsource some production to foreign unskilled labor. Within this framework, we look first at the effects of outsourcing when the labor 
markets are distorted by a minimum wage and then when they are undistorted. ${ }^{1}$ In both cases, we consider the welfare consequences of outsourcing by calculating the optimal subsidy for each unit of the oligopolist's exports and the optimal tax per unit of labor that is outsourced by the oligopolist.

In a minimum-wage economy the three types of labor are tightly linked: The presence of a competitive importing sector operating under constant returns to scale (CRS) fixes the skilled wage and, through the zero-profit condition, the unskilled/skilled wage ratio. Given a fixed wage ratio, the labor intensities of both sectors are fixed also. In equilibrium, the relative marginal productivities of unskilled domestic labor and unskilled outsourced labor must equal their relative wages. The marginal wage cost of outsourcing is the foreign wage plus the outsourcing tax, while the marginal wage cost of domestic unskilled labor is the minimum wage. Thus, for a given tax on outsourcing, the ratio of marginal wage costs is independent of the rest of the model. The marginal productivity ratio is shown to be a decreasing function of the level of outsourcing alone. Further, the equality between the marginal productivity ratio and the marginal wage cost ratio dictates that the level of outsourcing is a function only of the outsourcing tax and is independent of the rest of the model. Consequently, we find that a rise in foreign competition or a rise in the domestic export subsidy will have no effect on outsourcing.

In general, the purpose of an export subsidy to the domestic oligopolist is to increase national income by shifting profits from overseas oligopolists. When the domestic oligopolist operates in an economy whose labor market is distorted by a minimum wage, there is the additional concern of how the export subsidy affects the labor market. Depending on the relative labor intensities, the labor-

${ }^{1}$ For a treatment of minimum wages in general equilibrium trade models see Brecher (1974a and 1974b). 
market distortion may call for an augmentation of the profit shifting subsidy. In the case in which the oligopolistic sector is more unskilled-labor intensive than the competitive sector, a subsidy expands the oligopolist's output, thereby drawing resources from the competitive sector. As the competitive sector contracts, it releases more unskilled labor than can be absorbed by the oligopolistic sector at a fixed wage, thereby aggravating the unemployment problem. The optimal export policy will then be to reduce the export subsidy below the profit-shifting level and maybe even to impose an export tax.

Because there is unemployment in a minimum-wage economy, an optimal outsourcing tax is necessarily positive. It raises the net marginal cost of hiring foreign labor, thereby switching jobs from foreign labor to unemployed domestic workers. Given that for all potential or actual workers the opportunity cost of leisure is below the minimum wage, society gains from this switch. Of course, there may be limits to pursuing such a policy which reduces the profit of the oligopolistic firm and may lead to its exit.

Because outsourcing is linked to questions of international competitiveness, we also look at the effects of exogenous changes in the level of competition faced by the domestic oligopolist, which we capture by an increase in the number of foreign oligopolists. ${ }^{2}$ While the output of the oligopolistic sector must fall, it is not clear what happens to domestic employment. If the oligopolistic sector is more skilled-labor intensive, aggregate employment must rise because, as the oligopolistic sector shrinks, more skilled labor is laid off relative to unskilled labor. Given that labor intensities are fixed and that the competitive sector is relatively unskilled-labor intensive, it can absorb all the excess skilled labor only if

\footnotetext{
${ }^{2}$ Qualitatively similar results are obtained when considering a reduction in the marginal costs of foreign firms.
} 
it can match it by a correspondingly high unskilled labor absorption. This is possible only if the competitive sector draws from the unemployed pool of workers. Thus, in this particular case, a rise in international competition can reduce domestic unemployment, alleviate the labor-market distortion, and raise national income. However, if the oligopolistic sector is less skill intensive, the unemployment problem is aggravated by increased international competition and national income must fall.

When wages are market-clearing, outsourcing is affected not only by an outsourcing tax, but also by other parameters, including the export subsidy and the number of foreign firms. This is because any parameter change that affects the market-clearing wage also affects outsourcing. Consider a rise in the export subsidy in the oligopolistic sector. As output rises resources are drawn from the other sector. If the oligopolistic firm is relatively skill-intensive, it will require relatively less unskilled labor than what is released by the competitive sector and the excess supply of unskilled labor will reduce the unskilled wage. This reduction of the marginal wage cost of domestic labor will lead the firm to reduce outsourcing and raise the employment of domestic unskilled labor. Thus, an export subsidy will raise (reduce) outsourcing when the oligopolistic firm is intensive in unskilled (skilled) labor. The results are exactly reversed for an increase in the number of foreign firms, because a rise in the number of foreign firms leads to a reduction in the equilibrium level of output of the domestic firm.

National income can either rise or fall in response to increased foreign competition if the government is passive. As the number of foreign firms rise the domestic output reduction and the foreign output expansion both reduce national income. However, if the rise in the number of foreign firms reduces the domestic wage, then the domestic firm's output expands. In this situation, there is a possibility that national income may rise in the face of greater foreign competition. In contrast, under 
optimal intervention-when the outsourcing tax is zero and the export subsidy is at the profit-shifting level-an increase in the number of foreign firms must reduce national income.

Finally, for completeness, we consider the case of Bertrand competition, in which the profit shifting effect calls for a tax on the domestic oligopolist's exports (Eaton and Grossman, 1986). We show that in our model this effect remains and that the labor-market effect is identical to the case of Cournot competition.

\section{The Model}

We present a two-sector model in which the exporting sector is oligopolistic and the importcompeting sector is competitive. For analytical simplicity we assume that the oligopolistic sector consists of one domestic firm exporting a pure export good (i.e., there is no domestic consumption) and competes with foreign firms as a Cournot oligopolist in a third nation's market. We first describe the oligopolistic sector and then incorporate the competitive sector into the analysis.

\subsection{The Oligopolistic Sector}

The exporting firm uses two inputs, unskilled labor and skilled labor. Unskilled labor may be domestic or foreign (outsourced unskilled labor). If it is foreign, it is assumed to be less productive than domestic labor. Also, this productivity is assumed to diminish as more foreign labor is hired. The latter effect captures increasing costs that employers may face in trying to hire workers in less developed nations with institutional constraints such as a lack of a modern communication network, electricity services, etc. 
Let a unit of foreign labor provide the equivalent of $\delta<1$ units of domestic labor. Suppose that the firm hires $\mathrm{n}$ units of foreign labor (the level of outsourcing). We have assumed already that $\delta$ falls with $\mathrm{n}$. Furthermore, while the effective units of labor rise with $\mathrm{n}$, we assume that this increase becomes smaller as $\mathrm{n}$ rises. Thus the function $\delta(\mathrm{n})$ may be described as

$$
\delta=\delta(\mathrm{n})<1, \quad \delta^{\prime}(\mathrm{n})<0, \quad \delta+\mathrm{n} \delta^{\prime}>0, \quad \text { and } 2 \delta^{\prime}+\mathrm{n} \delta^{\prime \prime}<0 .
$$

The domestic production function is

$$
\mathrm{q}=\mathrm{F}\left(\mathrm{L}_{\mathrm{E}}+\mathrm{n} \delta(\mathrm{n}), \mathrm{S}_{\mathrm{E}}\right)
$$

where $\mathrm{F}($.$) is constant returns to scale, \mathrm{S}_{\mathrm{E}}$ is the level of skilled labor employed by the exporting firm, and $\mathrm{L}_{\mathrm{E}}$ is the level of domestic unskilled labor hired by the firm. Let the inverse demand function for the product be

$$
\mathrm{P}=\mathrm{P}(\mathrm{Q}), \quad \mathrm{Q}=\mathrm{q}+\mathrm{q}^{*}, \quad \mathrm{P}^{\prime}<0
$$

where $\mathrm{q}$ is the output of the domestic firm and $\mathrm{q}^{*}$ is the sum of the output levels of the foreign firms.

Foreign-firm j's profit is

$$
\pi_{\mathrm{j}}^{*}=\left(P-\mathrm{c}_{\mathrm{j}}^{*}\right) \mathrm{q}_{\mathrm{j}}^{*} \text {, }
$$

where $\mathrm{c}_{\mathrm{j}}^{*}$ and $\mathrm{q}_{\mathrm{j}}^{*}$ are, respectively, the constant marginal cost and output levels of firm $\mathrm{j}$. The first-order condition of profit maximization for a foreign firm is

$$
P-c_{j}^{*}+q_{j}^{*} P^{\prime}=0 .
$$

Adding the first-order conditions across the $\mathrm{m}$ foreign firms, we obtain

$$
\mathrm{mP}-\mathrm{c}^{*}+\mathrm{P}^{\prime} \mathrm{q}^{*}=0, \quad \text { where } \mathrm{q}^{*}=\sum \mathrm{q}_{\mathrm{j}}^{*} \text { and } \mathrm{c}^{*}=\sum \mathrm{c}_{\mathrm{j}}^{*} .
$$

Suppressing $\mathrm{c}^{*}$, relation $(4 \mathrm{c})$ implies the total foreign reaction function, $\mathrm{q}^{*}=\mathrm{q}^{*}(\mathrm{q}, \mathrm{m})$, with a slope of

$$
\rho^{*}=\partial q^{*} / \partial q=-\left(m P^{\prime}+q^{*} P^{\prime \prime}\right) /\left[(m+1) P^{\prime}+q^{*} P^{\prime \prime}\right] .
$$


The domestic firm is provided a unit export subsidy $\sigma$, and faces an outsourcing tax of $t$ per unit of foreign labor. Let the domestic wages be $\mathrm{w}$ for unskilled labor and $\mathrm{w}_{\mathrm{s}}$ for skilled labor. The firm is assumed to be small in factor markets and buys foreign labor at the price of $w_{0}$. The domestic firm's profit is

$$
\pi=(P+\sigma) q-w L_{E}-\left(w_{0}+t\right) n-w_{s} S_{E} .
$$

Using (2) and (3) and making the Cournot-Nash assumption that the home firm assumes that $\mathrm{q}^{*}$ is not affected by its choice of $\mathrm{q}$, the first-order conditions of profit maximization for the home firm are

$$
\begin{aligned}
& \partial \pi / \partial \mathrm{L}_{\mathrm{E}}=\left(\mathrm{P}+\sigma+\mathrm{qP}^{\prime}\right) \mathrm{F}_{1}(.)-\mathrm{w}=0, \\
& \partial \pi / \partial \mathrm{n}=\left(\mathrm{P}+\sigma+\mathrm{qP}^{\prime}\right) \mathrm{F}_{1}(.)\left[\delta+\mathrm{n} \delta^{\prime}(\mathrm{n})\right]-\left(\mathrm{w}_{0}+\mathrm{t}\right)=0, \text { and } \\
& \partial \pi / \partial \mathrm{S}_{\mathrm{E}}=\left(\mathrm{P}+\sigma+\mathrm{qP}^{\prime}\right) \mathrm{F}_{2}(.)-\mathrm{w}_{\mathrm{s}}=0 .
\end{aligned}
$$

Using (6a) in (6b), we see that outsourcing is reduced by an outsourcing tax:

$$
\delta(\mathrm{n})+\mathrm{n} \delta^{\prime}(\mathrm{n})=\left(\mathrm{w}_{0}+\mathrm{t}\right) / \mathrm{w} \Rightarrow \mathrm{n}=\mathrm{n}(\mathrm{t}, \mathrm{w}), \quad \partial \mathrm{n} / \partial \mathrm{t}=\mathrm{n}_{\mathrm{t}}=1 /\left[\mathrm{w}\left(2 \delta^{\prime}+\mathrm{n} \delta^{\prime \prime}\right)\right]<0 .
$$

Using (6a) and (6c),

$$
\mathrm{F}_{1}(.) / \mathrm{F}_{2}(.)=\mathrm{w} / \mathrm{w}_{\mathrm{s}}
$$

Given the homotheticity of F(.), (8a) implies that with $\mathrm{w}$ and $\mathrm{w}_{\mathrm{s}}$ given, the oligopolist's unskilled-labor intensity $\lambda_{\mathrm{E}}$ is determined from ( $\left.8 \mathrm{~b}\right)$ and is independent of other parameters of the model:

$$
\left[\mathrm{L}_{\mathrm{E}}+\mathrm{n} \delta(\mathrm{n})\right] / \mathrm{S}_{\mathrm{E}}=\lambda_{\mathrm{E}}=\lambda_{\mathrm{E}}\left(\mathrm{w} / \mathrm{w}_{\mathrm{s}}\right), \quad \lambda_{\mathrm{E}}^{\prime}<0
$$

Using the total foreign reaction function (4d) and the inverse demand function (3), the domestic oligopolist's marginal revenue as a function of its own output and the number of foreign oligopolists is

$$
\mathrm{R}(\mathrm{q}, \mathrm{m})=\mathrm{P}\left(\mathrm{q}+\mathrm{q}^{*}(\mathrm{q}, \mathrm{m})\right)+\mathrm{qP}^{\prime}\left(\mathrm{q}+\mathrm{q}^{*}(\mathrm{q}, \mathrm{m})\right), \quad \mathrm{R}_{\mathrm{q}}=\partial \mathrm{R} / \partial \mathrm{q}<0
$$


Substituting (9) into (6a), we obtain the domestic oligopolists's output as a function of the export subsidy, the number of foreign oligopolists, and wages:

$$
q=q\left(\sigma, m, w, w_{s}\right), \quad \partial q / \partial \sigma=-1 / R_{q}>0
$$

Using (2), (8b), and the CRS property of the production function, we obtain the total differential of the production function:

$$
\mathrm{q}=\mathrm{S}_{\mathrm{E}} \mathrm{F}\left(\lambda_{\mathrm{E}}, 1\right) \Rightarrow \mathrm{dq}=\mathrm{F}\left(\lambda_{\mathrm{E}}, 1\right) \mathrm{d} \mathrm{S}_{\mathrm{E}}+\mathrm{S}_{\mathrm{E}} \mathrm{F}_{1}(.) \lambda_{\mathrm{E}}^{\prime} \mathrm{d}\left(\mathrm{w} / \mathrm{w}_{\mathrm{s}}\right)
$$

\section{2: The Competitive Import-Competing Sector}

Let the competitive sector produce the import-competing numeraire good M. It is produced using skilled labor $\left(\mathrm{S}_{\mathrm{M}}\right)$ and unskilled labor $\left(\mathrm{L}_{\mathrm{M}}\right)$ through $\mathrm{CRS}$ technology. The zero-profit condition dictates that

$$
\mathrm{C}^{\mathrm{M}}\left(\mathrm{w}, \mathrm{w}_{\mathrm{s}}\right)=1
$$

where $\mathrm{C}^{\mathrm{M}}\left(\mathrm{w}, \mathrm{w}_{\mathrm{s}}\right)$ is the average cost function for a competitive firm. Relation (12a) defines

$$
\mathrm{w}_{\mathrm{s}}=\mathrm{f}(\mathrm{w})
$$

Let the production function for $\mathrm{M}$ be

$$
\mathrm{M}=\Phi\left(\mathrm{L}_{\mathrm{M}}, \mathrm{S}_{\mathrm{M}}\right)
$$

Competitive profit-maximization conditions imply the unskilled-labor intensity in $M, \lambda_{M}$ :

$$
\Phi_{1}\left(\mathrm{~L}_{\mathrm{M}}, \mathrm{S}_{\mathrm{M}}\right) / \Phi_{2}\left(\mathrm{~L}_{\mathrm{M}}, \mathrm{S}_{\mathrm{M}}\right)={ }_{\mathrm{w}} / \mathrm{w}_{\mathrm{s}}=\mathrm{w} / \mathrm{f}(\mathrm{w}) \Rightarrow \lambda_{\mathrm{M}}=\mathrm{L}_{\mathrm{M}} / \mathrm{S}_{\mathrm{M}}=\lambda_{\mathrm{M}}(\mathrm{w})
$$




\section{A Minimum-Wage Economy}

\section{1: Second-Best Policies}

Let $\mathrm{w}_{\mathrm{S}}$ be fixed by a minimum wage set at $\overline{\mathrm{w}}$. Using $(12 \mathrm{~b})$,

$$
w_{S}=f(\bar{w})=\bar{w}_{s} .
$$

Using (8b), (14), and (15a), the unskilled-labor intensities in both sectors are fixed by the minimum wage:

$$
\lambda_{\mathrm{E}}=\bar{\lambda}_{\mathrm{E}} \text { and } \lambda_{\mathrm{M}}=\bar{\lambda}_{\mathrm{M}}
$$

Using (10), (11), (15a), and (15b), the output of the domestic oligopolist is unaffected by the outsourcing tax, as is its use of unskilled labor:

$$
\partial \mathrm{q} / \partial \mathrm{t}=0 \Rightarrow \mathrm{F}\left(\lambda_{\mathrm{E}}, 1\right) \partial \mathrm{S}_{\mathrm{E}} / \partial \mathrm{t}=0 \Rightarrow \partial \mathrm{S}_{\mathrm{E}} / \partial \mathrm{t}=0
$$

Using (16a) and considering the factor-market equilibrium condition for skilled labor,

$$
\mathrm{S}_{\mathrm{E}}+\mathrm{S}_{\mathrm{M}}=\overline{\mathrm{S}} \Rightarrow \partial \mathrm{S}_{\mathrm{M}} / \partial \mathrm{t}=0
$$

Using (10) and (11), an export subsidy shifts skilled labor from the import-competing sector to the oligopolist:

$$
\partial \mathrm{S}_{\mathrm{M}} / \partial \sigma=-\partial \mathrm{S}_{\mathrm{E}} / \mathrm{d} \sigma=-(\partial \mathrm{q} / \partial \sigma) / \mathrm{F}\left(\lambda_{\mathrm{E}}, 1\right)=1 /\left[\mathrm{R}_{\mathrm{q}}(\mathrm{q}, \mathrm{m}) \mathrm{F}\left(\lambda_{\mathrm{E}}, 1\right)\right]<0
$$

Using (17) and noting from (15b) that $\lambda_{M}$ and $\lambda_{E}$ are fixed, we have

$$
\begin{aligned}
& \operatorname{dln}\left(\lambda_{\mathrm{M}}\right)=0 \Rightarrow \partial \mathrm{L}_{\mathrm{M}} / \partial \mathrm{t}=\partial \mathrm{S}_{\mathrm{M}} / \partial \mathrm{t}=0 \text { and } \partial \mathrm{L}_{\mathrm{M}} / \partial \sigma=\lambda_{\mathrm{M}} \partial \mathrm{S}_{\mathrm{M}} / \partial \sigma<0 \text {, along with } \\
& \operatorname{dln}\left(\lambda_{\mathrm{E}}\right)=0 \Rightarrow \partial \mathrm{L}_{\mathrm{E}} / \partial \mathrm{t}=-\left(\delta+\mathrm{n} \delta^{\prime}\right) \mathrm{n}_{\mathrm{t}}>0 \text { and } \partial \mathrm{L}_{\mathrm{E}} / \partial \sigma=\lambda_{\mathrm{E}} \partial \mathrm{S}_{\mathrm{E}} / \partial \sigma>0 .
\end{aligned}
$$

Unskilled labor in the import-competing sector is unaffected by an outsourcing tax but is decreased by and export subsidy. In contrast, unskilled labor is increased by both policies. 
Let $\mathrm{L}$ and $\overline{\mathrm{L}}$ denote the total of employed unskilled labor in the home nation and the endowment of unskilled labor, respectively. Let $\mathrm{b}$ denote the amount that is obtained by the unemployed workers (same as the marginal social cost of employing one more unit of labor) and $\mathrm{L}_{u}$ denote the units of labor hours that are unemployed. National income is then

$$
\mathrm{NI}=\pi-\sigma q+w L+b L_{u}+t n+w_{s} \bar{S} .
$$

Note that

$$
\mathrm{L}=\mathrm{L}_{\mathrm{E}}+\mathrm{L}_{\mathrm{M}}, \quad \text { and } \quad \mathrm{L}_{\mathrm{E}}+\mathrm{L}_{\mathrm{M}}+\mathrm{L}_{\mathrm{u}}=\overline{\mathrm{L}} \text {. }
$$

Using (15a), (16b), (20), and the expression for the domestic firm's profit, (19) reduces to

$$
\mathrm{NI}=\mathrm{Pq}+(\overline{\mathrm{W}}-\mathrm{b}) \mathrm{L}_{\mathrm{M}}-\mathrm{W}_{0} \mathrm{n}+\overline{\mathrm{W}}_{\mathrm{S}} \mathrm{S}_{\mathrm{M}}+\mathrm{b}\left(\overline{\mathrm{L}}-\mathrm{L}_{\mathrm{E}}\right) .
$$

Total differentiation of (21) yields

$$
\mathrm{dNI}=\left(\mathrm{qP}^{\prime} \rho^{*}+\mathrm{R}\right) \mathrm{dq}+(\overrightarrow{\mathrm{w}}-\mathrm{b}) \mathrm{dL}_{\mathrm{M}}-\mathrm{w}_{0} \mathrm{dn}+\overline{\mathrm{w}}_{\mathrm{s}} \mathrm{dS}_{\mathrm{M}}-\mathrm{bdL} \mathrm{L}_{\mathrm{E}} .
$$

Using (7), (10), (11), and (16a) through (18), we can reduce (22a) to

$$
\begin{aligned}
\mathrm{dNI}= & {\left[\left(\mathrm{qP}^{\prime} \rho^{*}+\mathrm{R}\right) \mathrm{F}\left(\lambda_{\mathrm{E}}, 1\right)-(\overline{\mathrm{w}}-\mathrm{b}) \lambda_{\mathrm{M}}-\overline{\mathrm{W}}_{\mathrm{s}}-\mathrm{b} \lambda_{\mathrm{E}}\right]\left(\partial \mathrm{S}_{\mathrm{E}} / \mathrm{d} \sigma\right) \mathrm{d} \sigma } \\
& +\left[\mathrm{b}\left(\delta+\mathrm{n} \delta^{\prime}\right)-\mathrm{w}_{0}\right] \mathrm{n}_{\mathrm{t}} \mathrm{dt} .
\end{aligned}
$$

Using (7) and (22b), we can derive the optimal outsourcing tax as

$$
\mathrm{b}\left(\delta+\mathrm{n} \delta^{\prime}\right)=\mathrm{w}_{0} \Rightarrow \mathrm{t}_{\mathrm{opt}}=\left(\mathrm{w}_{0} / \mathrm{b}\right)((\overline{\mathrm{w}}-\mathrm{b})>0 .
$$

Notice that it is optimal to tax outsourcing because the minimum wage exceeds the opportunity value of leisure.

By (7), (18), and (20), the outsourcing tax reduces the number of unemployed unskilled workers:

$$
\partial \mathrm{L}_{\mathrm{u}^{\prime}} / \partial \mathrm{t}=-\left[\left(\partial \mathrm{L}_{\mathrm{E}} / \partial \mathrm{t}\right)+\left(\partial \mathrm{L}_{\mathrm{M}} / \partial \mathrm{t}\right)\right]=-\left(\partial \mathrm{L}_{\mathrm{E}} / \partial \mathrm{t}\right)=\left(\delta+\mathrm{n} \delta^{\prime}\right) \mathrm{n}_{\mathrm{t}}<0
$$


Note from (10) and (15a) through (16b) that $\mathrm{q}, \lambda_{\mathrm{E}}$, and $\mathrm{S}_{\mathrm{E}}$ do not change with $\mathrm{t}$ (given $\sigma$ ). However, notice from (7) that the outsourcing tax must reduce n, so $L_{E}$ must rise enough to keep the labor intensity unchanged. From (18) we can see that $\mathrm{L}_{\mathrm{M}}$ does not change with $\mathrm{t}$. Therefore, with the imposition of an outsourcing tax, all the extra domestic employment in sector E comes from the pool of unemployed workers, partially alleviating the labor-market distortion and raising welfare.

Let us now consider the national-income-maximizing first-order condition for the export subsidy:

$$
\left(\mathrm{qP}^{\prime} \rho^{*}+\mathrm{R}\right) \mathrm{F}\left(\lambda_{\mathrm{E}}, 1\right)-(\overline{\mathrm{w}}-\mathrm{b}) \lambda_{\mathrm{M}}-\overline{\mathrm{w}}_{\mathrm{s}}-\mathrm{b} \lambda_{\mathrm{E}}=0 .
$$

From (6c), we have $\overline{\mathrm{w}}_{\mathrm{s}}=(\sigma+\mathrm{R}) \mathrm{F}_{2}$. Substituting this expression for $\overline{\mathrm{w}}_{\mathrm{s}}$ into (25) and using (6a) and the CRS property that $F\left(\lambda_{E}, 1\right)=\lambda_{E} F_{1}+F_{2}$, we get the optimal export subsidy:

$$
\sigma_{\text {opt }}=(\overline{\mathrm{w}}-\mathrm{b})\left(\lambda_{\mathrm{E}}-\lambda_{\mathrm{M}}\right) / \mathrm{F}\left(\lambda_{\mathrm{E}}, 1\right)+\mathrm{qP}^{\prime} \rho^{*} .
$$

While the optimal outsourcing tax is unambiguously positive, it is not clear whether it is optimal to subsidize or to tax exports. Whereas the profit-shifting motive suggests an export subsidy, a subsidy alleviates the labor-market distortion if and only if the labor intensity of sector E exceeds that of sector M. Therefore, when $\lambda_{M}$ exceeds $\lambda_{E}$ a export tax might be optimal. ${ }^{3}$

Using (18) and (20) we have the marginal effect of the export subsidy on unemployment:

${ }^{3}$ This contrasts Brander and Spencer (1988), where under Cournot competition (associated with downward sloping firm reaction functions in output space), it is always optimal to subsidize a unionized firm. The subsidy in that paper is actually larger than the traditional strategic subsidy (for a nonunionized firm), because in addition to shifting profits, it also corrects for the labor market distortion due to unionization. Somewhat analogously, our subsidy (or tax) corrects for the labor market distortion due to the minimum wage, however, this correction may either add to the traditional strategic subsidy or subtract from it depending on the relative labor intensities. 


$$
\partial \mathrm{L}_{\mathrm{u}} / \partial \sigma=-\left[\left(\partial \mathrm{L}_{\mathrm{E}} / \partial \sigma\right)+\left(\partial \mathrm{L}_{\mathrm{M}} / \partial \sigma\right)\right]=-\left[\mathrm{q}^{\prime}(\sigma) / \mathrm{F}\left(\lambda_{\mathrm{E}}, 1\right)\right]\left(\lambda_{\mathrm{E}}-\lambda_{\mathrm{M}}\right) .
$$

A rise in the export subsidy will reduce unemployment if and only if the unskilled-labor intensity in the oligopolistic sector is higher than that in the import-competing sector $\left(\lambda_{E}>\lambda_{M}\right)$. When an export subsidy expands output in the oligopolistic sector, it needs more of both types of labor, because the labor intensity is fixed by $\mathrm{w}$. However, $\mathrm{n}$ is independent of the subsidy and, therefore, the expansion of unskilled-labor employment in the oligopolistic sector comes entirely from domestic labor. As the employment of skilled labor rises in the oligopolistic sector, sector M contracts to provide it. However, its unskilled-labor intensity is also fixed because $\mathrm{w}$ is given. As M contracts, it releases unskilled labor. If the oligopolistic sector has the higher unskilled-labor intensity, it will need more unskilled labor than is released by sector M. This is provided by the unemployed pool of workers and unemployment falls. In the same vein, if the oligopolistic sector is less unskilled-labor intensive $\left(\lambda_{E}<\lambda_{M}\right)$, the labor-market distortion is aggravated by the subsidy. Therefore the optimal subsidy is lower than the profit-shifting level in this latter scenario. Moreover, if in this latter case the labor-market effect dominates, an export tax is optimal. Of course, as noted in the previous section, such a policy may not be feasible to employ because it reduces firm profit and may lead the home firm to exit the country.

\section{2: Increased Foreign Competition}

We can capture the effects of increased foreign competition either by raising the number of foreign firms or by reducing the foreign marginal cost of production. They have qualitatively similar effects. We focus here on the case in which the number of foreign firms in the oligopolistic market, $\mathrm{m}$, rises. Recall from (4d) and (9) that 


$$
\mathrm{P}\left(\mathrm{q}+\mathrm{q}^{*}(\mathrm{q}, \mathrm{m})\right)+\mathrm{qP}^{\prime}\left(\mathrm{q}+\mathrm{q}^{*}(\mathrm{q}, \mathrm{m})\right)=\mathrm{R}(\mathrm{q}, \mathrm{m}) .
$$

Using (6a), (15b), and (28)

$$
[R(q, m)+\sigma] F_{1}\left(\bar{\lambda}_{E}, 1\right)=\bar{w} \Rightarrow q=q(m, \sigma), \quad \partial q / \partial m=-(\partial R / \partial m) /(\partial R / \partial q) .
$$

From (9) we know that $\partial \mathrm{R} / \partial \mathrm{q}<0$. Also, the marginal revenue of the domestic firm falls with an increase in the number of foreign firms:

$$
\partial \mathrm{R} / \partial \mathrm{m}=-\left(\mathrm{P}^{\prime}+\mathrm{qP} \mathrm{P}^{\prime \prime}\right) \mathrm{P} /\left[(\mathrm{m}+1) \mathrm{P}^{\prime}+\mathrm{q}^{*} \mathrm{P}^{\prime \prime}\right]<0 .
$$

Thus, $\partial \mathrm{q} / \partial \mathrm{m}<0$, the output of the domestic firm is reduced by increased foreign competition. Using (11) and (30), we can see that employment of skilled workers falls when there is increased foreign competition:

$$
\partial \mathrm{S}_{\mathrm{E}} / \partial \mathrm{m}=(\partial \mathrm{q} / \partial \mathrm{m}) / \mathrm{F}\left(\lambda_{\mathrm{E}}, 1\right)<0 .
$$

Note that $\lambda_{E}=\bar{\lambda}_{E}, \lambda_{M}=\bar{\lambda}_{M}, S_{M}+S_{E}=\bar{S}$, and $n$ is independent of $m$. Therefore, when $m$ rises, the domestic firm employs fewer unskilled workers, some of whom are shifted to the import-competing sector.

$$
\partial \mathrm{L}_{\mathrm{E}} / \partial \mathrm{m}=\bar{\lambda}_{\mathrm{E}}\left(\partial \mathrm{S}_{\mathrm{E}} / \partial \mathrm{m}\right)<0 \quad \text { and } \quad \partial \mathrm{L}_{\mathrm{M}} / \partial \mathrm{m}=\bar{\lambda}_{\mathrm{M}}\left(\partial \mathrm{S}_{\mathrm{M}} / \partial \mathrm{m}\right)=-\bar{\lambda}_{\mathrm{M}}\left(\partial \mathrm{S}_{\mathrm{E}} / \partial \mathrm{m}\right)>0
$$

The effect on total employment of unskilled workers depends on the relative unskilled-labor intensities of the two sectors:

$$
\partial\left(\mathrm{L}_{\mathrm{M}}+\mathrm{L}_{\mathrm{E}}\right) / \partial \mathrm{m}=\left(\bar{\lambda}_{\mathrm{E}}-\bar{\lambda}_{\mathrm{M}}\right)\left(\partial \mathrm{S}_{\mathrm{E}} / \partial \mathrm{m}\right)>/<0 \text { as } \bar{\lambda}_{\mathrm{E}}<>\bar{\lambda}_{\mathrm{M}},
$$

as does the number of unemployed unskilled workers:

$$
\partial \mathrm{L}_{\mathrm{u}} / \partial \mathrm{m}=-\left(\bar{\lambda}_{\mathrm{E}}-\bar{\lambda}_{\mathrm{M}}\right)\left(\partial \mathrm{S}_{\mathrm{E}} / \partial \mathrm{m}\right)>/<0 \text { as } \bar{\lambda}_{\mathrm{E}}>k \bar{\lambda}_{\mathrm{M}} .
$$

Therefore, given $t$ and $\sigma$, increased competition in the oligopolistic sector will increase (reduce) unemployment if sector $\mathrm{E}$ is (less) intensive in skilled labor than is the import-competing sector. 
Let us now explore the effect on national income, which, using (4d) and (21) is

$$
\mathrm{NI}(\sigma, \mathrm{t}, \mathrm{m})=\mathrm{P}\left(\mathrm{q}+\mathrm{q}^{*}(\mathrm{q}, \mathrm{m})\right) \mathrm{q}+(\overline{\mathrm{w}}-\mathrm{b}) \mathrm{L}_{\mathrm{M}}-\mathrm{w}_{0} \mathrm{n}+\overline{\mathrm{w}}_{\mathrm{s}} \mathrm{S}_{\mathrm{M}}+\mathrm{b}\left(\overline{\mathrm{L}}-\mathrm{L}_{\mathrm{E}}\right)
$$

Total differentiation of (34) yields

$$
\begin{aligned}
\mathrm{dNI}= & {\left[\mathrm{qP}^{\prime}\left(\partial \mathrm{q}^{*} / \partial \mathrm{m}\right)+\mathrm{A}(\mathrm{dq} / \mathrm{dm})\right] \mathrm{dm}+\mathrm{A}(\partial \mathrm{q} / \partial \sigma) \mathrm{d} \sigma+\left[\mathrm{b}\left(\delta+\mathrm{n} \delta^{\prime}\right)-\mathrm{w}_{0}\right] \mathrm{n}_{\mathrm{t}} \mathrm{dt}, } \\
& \text { where } \mathrm{A}=(\overline{\mathrm{w}}-\mathrm{b})\left(\lambda_{\mathrm{E}}-\lambda_{\mathrm{M}}\right) / \mathrm{F}\left(\lambda_{\mathrm{E}}, 1\right)+\mathrm{qP}^{\prime} \rho^{*}-\sigma .
\end{aligned}
$$

Relation (34) presents a general expression that is useful for analyzing changes in national income. We focus on two special cases: when there is no government intervention and when government intervention is optimal.

Case 1: No Intervention $(\sigma \equiv t \equiv 0)$

$$
\begin{aligned}
& \mathrm{dNI} / \mathrm{dm}=\mathrm{qP}^{\prime}\left(\partial \mathrm{q}^{*} / \partial \mathrm{m}\right)+\mathrm{A}(\mathrm{dq} / \mathrm{dm}) \\
& \quad=\mathrm{qP}^{\prime}\left(\partial \mathrm{q}^{*} / \partial \mathrm{m}\right)+\left[\mathrm{qP}^{\prime} \rho^{*}+(\overline{\mathrm{w}}-\mathrm{b})\left(\lambda_{\mathrm{E}}-\lambda_{\mathrm{M}}\right) / \mathrm{F}\left(\lambda_{\mathrm{E}}, 1\right)\right] \mathrm{dq} / \mathrm{dm} .
\end{aligned}
$$

Now $\partial \mathrm{q}^{*} / \partial \mathrm{m}>0$ and $\mathrm{dq} / \mathrm{dm}<0$. Thus, $\mathrm{dNI} / \mathrm{dm}<0$ if $\lambda_{\mathrm{E}} \geq \lambda_{\mathrm{M}}$, and has an ambiguous sign if $\lambda_{\mathrm{E}}<\lambda_{\mathrm{M}}$. Thus, increased competition from foreign firms will not necessarily reduce home welfare. If it leads to sectoral reallocations such that unemployment is reduced, then national income may actually increase.

Case 2: Optimal Intervention $\left(\sigma \equiv \sigma_{\mathrm{opt}}, \mathrm{t} \equiv \mathrm{t}_{\mathrm{opt}}\right)$

Under optimal policy intervention $A(\partial q / \partial \sigma)=0 \Rightarrow A=0$ and $b\left(\delta+n \delta^{\prime}\right)=w_{0}$. Therefore,

$$
\mathrm{dNI} / \mathrm{dm}=\mathrm{qP}^{\prime}\left(\partial \mathrm{q}^{*} / \partial \mathrm{m}\right)<0
$$

If optimal policies are already in place, a rise in foreign competition must reduce national income. 


\section{Equilibrium under Flexible Wages}

When wages are flexible, the labor-market equilibrium condition is

$$
\mathrm{L}_{\mathrm{E}}+\mathrm{L}_{\mathrm{M}}=\overline{\mathrm{L}} \text {. }
$$

Using (8b), (37a) becomes

$$
\lambda_{\mathrm{E}} \mathrm{S}_{\mathrm{E}}+\lambda_{\mathrm{M}} \mathrm{S}_{\mathrm{M}}-\mathrm{n} \delta(\mathrm{n})=\overline{\mathrm{L}}
$$

From (12b) we know that $\mathrm{w}_{\mathrm{s}}$ is a function of $\mathrm{w}$. Using (7), (8a), (8b), (11), and (14), and noting that the $S_{E}$ and $S_{M}$ sum to $\bar{S}$, we have

$$
\begin{aligned}
& {\left[\lambda_{E}(w)-\lambda_{M}(w)\right] S_{E}-n(t, w) \delta(n(t, w))+\lambda_{M}(w) \bar{S}=\bar{L}} \\
& \Rightarrow\left[\mathrm{q} / F\left(\lambda_{E}(w), 1\right)\right]\left[\lambda_{E}(w)-\lambda_{M}(w)\right]-n(t, w) \delta(n(t, w))+\lambda_{M}(w) \bar{S}=\bar{L} .
\end{aligned}
$$

Using (10) and (12b),

$$
q=q(\sigma, m, w, f(w))=q(\sigma, m, w)
$$

Using $\left(10^{\prime}\right)$ in $(38 \mathrm{a})$,

$$
\left[\mathrm{q}(\sigma, \mathrm{m}, \mathrm{w}) / \mathrm{F}\left(\lambda_{\mathrm{E}}(\mathrm{w}), 1\right)\right]\left[\lambda_{\mathrm{E}}(\mathrm{w})-\lambda_{\mathrm{M}}(\mathrm{w})\right]-\mathrm{n}(\mathrm{t}, \mathrm{w}) \delta(\mathrm{n}(\mathrm{t}, \mathrm{w}))+\lambda_{\mathrm{M}}(\mathrm{w}) \overline{\mathrm{S}}=\overline{\mathrm{L}} \text {. }
$$

Relation (38b) implicitly defines the market clearing wage

$$
\mathrm{w}=\mathrm{w}(\sigma, \mathrm{t}, \mathrm{m}),
$$

where $^{4}$

$$
\begin{aligned}
& \mathrm{w}_{\sigma}=-\left[\left(\lambda_{\mathrm{E}}-\lambda_{\mathrm{M}}\right) / \mathrm{F}\left(\lambda_{\mathrm{E}}, 1\right)\right][\partial \mathrm{q}(\sigma, \mathrm{m}, \mathrm{w}) / \partial \sigma] / \partial\left(\mathrm{L}_{\mathrm{E}}^{\mathrm{d}}+\mathrm{L}_{\mathrm{M}}^{\mathrm{d}}\right) / \partial \mathrm{w}>/<0 \text { as } \lambda_{\mathrm{E}}>/<\lambda_{\mathrm{M}}, \\
& \mathrm{w}_{\mathrm{m}}=-\left[\left(\lambda_{\mathrm{E}}-\lambda_{\mathrm{M}}\right) / \mathrm{F}\left(\lambda_{\mathrm{E}}, 1\right)\right][\partial \mathrm{q}(\sigma, \mathrm{m}, \mathrm{w}) / \partial \mathrm{m}] / \partial\left(\mathrm{L}_{\mathrm{E}}^{\mathrm{d}}+\mathrm{L}_{\mathrm{M}}^{\mathrm{d}}\right) / \partial \mathrm{w}</>0 \quad \text { as } \lambda_{\mathrm{E}}>/<\lambda_{\mathrm{M}} \text {, } \\
& \text { and } \mathrm{w}_{\mathrm{t}}=[\partial \mathrm{n}(\mathrm{w}, \mathrm{t}) / \partial \mathrm{t}]\left(\delta+\mathrm{n} \delta^{\prime}\right) / \partial\left(\mathrm{L}_{\mathrm{E}}^{\mathrm{d}}+\mathrm{L}_{\mathrm{M}}^{\mathrm{d}}\right) / \partial \mathrm{w}>0
\end{aligned}
$$

\footnotetext{
4 The excess demand for domestic labor is $\left(\mathrm{L}_{\mathrm{E}}^{\mathrm{d}}+\mathrm{L}_{\mathrm{M}}^{\mathrm{d}}\right)-\overline{\mathrm{L}}$. To guarantee a stable equilibrium in the factor market, we assume that $\partial\left(\mathrm{L}_{\mathrm{E}}^{\mathrm{d}}+\mathrm{L}_{\mathrm{M}}^{\mathrm{d}}\right) / \partial \mathrm{w}<0$.
} 


\section{1: Effects on Outsourcing}

Using (7) and (38c) we have outsourcing as a function of government policies and the degree of foreign competition:

$$
\mathrm{n}=\mathrm{n}(\mathrm{w}(\sigma, \mathrm{t}, \mathrm{m}), \mathrm{t}) .
$$

It is easy to check that $n_{w}=\partial n(w, t) / \partial w>0$. Therefore, using this and (38d) - (38f), the effects of the policy variables and foreign competition on outsourcing are

$$
\begin{aligned}
& \mathrm{dn} / \mathrm{d} \sigma=\mathrm{w}_{\sigma} \mathrm{n}_{\mathrm{w}}>/<0 \text { as } \lambda_{\mathrm{E}}>/<\lambda_{\mathrm{M}}, \\
& \mathrm{dn} / \mathrm{dm}=\mathrm{w}_{\mathrm{m}} \mathrm{n}_{\mathrm{w}}</>0 \text { as } \lambda_{\mathrm{E}}>/<\lambda_{\mathrm{M}} \text {, and } \\
& \mathrm{dn} / \mathrm{dt}=\mathrm{w}_{\mathrm{t}} \mathrm{n}_{\mathrm{w}}+\mathrm{n}_{\mathrm{t}} .
\end{aligned}
$$

If the oligopolist is more unskilled-labor intensive than is the import-competing sector, outsourcing will be increased by an export subsidy and reduced by an increase in foreign competition. The first result is to be expected because greater foreign competition is like a tax on domestic output. However, as can be seen from (39b) and (39c), the effects of these changes on outsourcing depend directly on the relative factor intensities in the two sectors. There is some ambiguity regarding the sign of $\mathrm{dn} / \mathrm{dt}$ because of the induced wage effect $w_{t} n_{w}$. However, if the direct effect $n_{t}$ dominates, outsourcing must decline as $t$ is raised.

\section{2: National Income under Wage Flexibility}

Using (19) and noting that there is no unemployment (i.e., $\mathrm{L}_{u}=0$ ),

$$
\mathrm{NI}=\mathrm{Pq}+\mathrm{wL}_{\mathrm{M}}+\mathrm{w}_{\mathrm{s}} \mathrm{S}_{\mathrm{M}}-\mathrm{w}_{0} \mathrm{n} .
$$


The total differential of (40) can be reduced to

$$
\mathrm{dNI}=\mathrm{Bd} \sigma+\mathrm{Cdm}+\mathrm{Gdt},
$$

where $B=\left(q P^{\prime} \rho^{*}-\sigma\right)\left(q_{\sigma}+q_{w} w_{\sigma}\right)+t_{w} w_{\sigma}$,

$$
\begin{aligned}
& \mathrm{C}=\left(\mathrm{qP} \mathrm{P}^{\prime} \rho^{*}-\sigma\right)\left(\mathrm{q}_{\mathrm{m}}+\mathrm{q}_{\mathrm{w}} \mathrm{w}_{\mathrm{m}}\right)+\mathrm{qP}^{\prime}\left(\partial \mathrm{q}^{*} / \partial \mathrm{m}\right)+\mathrm{tn}_{\mathrm{w}} \mathrm{w}_{\mathrm{m}} \text {, and } \\
& \mathrm{G}=\left(\mathrm{qP}^{\prime} \rho^{*}-\sigma\right) \mathrm{q}_{\mathrm{w}} \mathrm{w}_{\mathrm{t}}+\mathrm{t}\left(\mathrm{n}_{\mathrm{w}} \mathrm{w}_{\mathrm{t}}+\mathrm{n}_{\mathrm{t}}\right) .
\end{aligned}
$$

Using (41), the optima for $\sigma$ and $t$ are attained where B and $G$ equal zero. Simultaneous solutions for these two first-order conditions imply that

$$
\mathrm{t}_{\mathrm{opt}}=0 \text { and } \sigma_{\text {opt. }}=\mathrm{qP}^{\prime} \rho^{*}>0 \text {. }
$$

Thus, optimal policies differ substantially from when there is a minimum wage. In the absence of labormarket distortions, the optimal outsourcing tax is zero, whereas the existence of unemployed workers in a minimum-wage economy makes an outsourcing tax optimal. Similarly, with wage flexibility the optimal export subsidy need only account for the profit-shifting motive and is unambiguously positive.

To examine the effect of foreign competition on welfare we focus on the same two cases we examined previously (no intervention and optimal intervention) along with the case in which government policy is constrained by WTO rules that prohibit export subsidies.

Case 1: No Intervention $(\sigma=t=0)$

$$
d N I / d m=C=q P^{\prime} \rho^{*}\left(q_{m}+q_{w} w_{m}\right)+q P^{\prime}\left(\partial q^{*} / \partial m\right) .
$$

There is some ambiguity regarding the sign of $\mathrm{dNI} / \mathrm{dm}$, because, based on (38e), we know that the sign of $\mathrm{w}_{\mathrm{m}}$ depends on the relative factor intensities of the two sectors. If the import-competing sector is at

\footnotetext{
${ }^{5}$ A proof is available from authors on request.
} 
least as unskilled-labor intensive as the oligopolist $\left(\lambda_{\mathrm{E}} \leq \lambda_{\mathrm{M}}\right), \mathrm{dNI} / \mathrm{dm}$ is necessarily negative. This is because the domestic wage rises along with $\mathrm{m}$ and acts in the same way as an output tax on the domestic firm, thereby hurting the firm in its market share rivalry with foreign firms. Of course, if $\lambda_{\mathrm{E}}>$ $\lambda_{M}$ domestic national income might rise along with the level of foreign competition faced by the domestic oligopolist. In this case, $\mathrm{w}$ falls as $\mathrm{m}$ rises, boosting the domestic oligopolist's profit, thereby making it impossible to rule out an increase in domestic national income when foreign competition increases. Note that these results reverse those from the minimum-wage economy (35a), for which $\mathrm{dNI} / \mathrm{dm}<0$ when $\lambda_{\mathrm{E}} \geq \lambda_{\mathrm{M}}$, and was ambiguous otherwise.

Case 2: Optimal Intervention $\left(\sigma \equiv \sigma_{\text {opt }}, t \equiv t_{\text {opt }}\right)$

Using (41) and (42), increased foreign competition will unambiguously reduce national income when the export subsidy and outsourcing tax are at their optimal levels:

$$
\mathrm{dNI} / \mathrm{dm}=\mathrm{C}=\mathrm{qP}^{\prime}\left(\partial \mathrm{q}^{*} / \partial \mathrm{m}\right)<0 .
$$

Note that this result is identical to that for the minimum-wage economy.

\section{Case 3: WTO-Restricted Intervention $\left(\sigma \equiv 0, t \equiv t_{\text {opt }}\right)$}

This case requires a recalculation of the optimal export tax, which was derived above simultaneously with the optimal export subsidy. Solving for when $G=0$, the second-best optimal outsourcing tax is

$$
\mathrm{t}_{\mathrm{SB}}=-\mathrm{qP}^{\prime} \rho^{*} \mathrm{q}_{\mathrm{w}} \mathrm{w}_{\mathrm{t}} /\left(\mathrm{n}_{\mathrm{w}} \mathrm{w}_{\mathrm{t}}+\mathrm{n}_{\mathrm{t}}\right) \text {. }
$$

Assume that $\left(n_{w} w_{t}+n_{t}\right)<0$, which, as in $(39 d)$, occurs when the direct effect of the outsourcing tax dominates the indirect effect on the unskilled wage. Noting that (38f) requires that $\mathrm{w}_{\mathrm{t}}>0$, we obtain the result that the second-best outsourcing tax is negative. This suggests that rather than taxing 
outsourcing, it should be subsidized if the focus is to raise national income through the capture of foreign rents. In other words, when direct export subsidies are ruled out, outsourcing is beneficial in terms of competing in international oligopolistic markets. The subsidization of outsourcing allows the domestic oligopolist to extract rents, which cannot be extracted by the usual means of an export subsidy.

The impact on national income of a greater degree of foreign competition is

$$
\mathrm{dNI} / \mathrm{dm}=\mathrm{qP}^{\prime} \rho^{*}\left(\mathrm{q}_{\mathrm{m}}+\mathrm{q}_{\mathrm{w}} \mathrm{w}_{\mathrm{m}}\right)+\mathrm{qP}^{\prime}\left(\partial \mathrm{q}^{*} / \partial \mathrm{m}\right)+\mathrm{t}_{\mathrm{SB}} \mathrm{n}_{\mathrm{w}} \mathrm{w}_{\mathrm{m}} .
$$

If $\lambda_{E} \leq \lambda_{M}$, the effect on national income from an increase in foreign competition is clearly negative.

This is because we know from (38e) that $\mathrm{w}_{\mathrm{m}} \geq 0$ in such a case, and because $\mathrm{t}_{\mathrm{SB}}<0$. On the other hand, if $\mathrm{w}_{\mathrm{m}}<0$, the effect of foreign competition on national income cannot be signed unambiguously.

\section{A Minimum-Wage Bertrand Economy}

This section considers price competition between a domestic firm and a foreign firm producing differentiated goods that are ordinary substitutes. ${ }^{6}$ We maintain the assumption that these products are for a third country's market. Denote the domestic and foreign firms as firm 1 and firm 2, respectively, producing quantities $\mathrm{q}^{1}$ and $\mathrm{q}^{2}$ sold at prices $\mathrm{p}^{1}$ and $\mathrm{p}^{2}$. The direct demand functions for the two varieties are

$$
\begin{aligned}
& q^{1}=D^{1}\left(p^{1}, p^{2}\right) \quad \text { where } \quad D_{1}^{1}<0 \quad \text { and } \quad D_{2}^{1}>0 \\
& q^{2}=D^{2}\left(p^{1}, p^{2}\right) \quad \text { where } D_{1}^{2}>0 \text { and } D_{2}^{2}<0 .
\end{aligned}
$$

\footnotetext{
${ }^{6}$ It is important to see whether our results are sensitive to the mode of strategic competition. For example, the Eaton and Grossman (1986) paper shows that if the mode of strategic export competition changes from Cournot to Bertrand, the optimal trade policy switches from an export subsidy to an export tax.
} 
Profit of the foreign firm is:

$$
\pi^{2}=\left(p^{2}-c^{2}\right) D^{2}\left(p^{1}, p^{2}\right)
$$

where $\mathrm{c}^{2}$ is assumed to be the foreign firm's constant marginal cost. Under the Bertrand conjecture, the foreign firm chooses its profit-maximizing price taking the domestic firm's price as given. The foreign firm's first-order condition for profit maximization is, therefore,

$$
\left(p^{2}-c^{2}\right) D_{2}^{2}+D^{2}\left(p^{1}, p^{2}\right)=0
$$

The first-order condition implies the Bertrand reaction function of the foreign firm, which, as is well know, is likely to be increasing in the other firm's price (which is unambiguous when the direct demand functions are linear):

$$
\mathrm{p}^{2}=\mathrm{p}^{2}\left(\mathrm{p}^{1}\right), \quad \text { where } \partial \mathrm{p}^{2} / \partial \mathrm{p}^{1}=\rho_{\mathrm{B}}^{*} .
$$

Relation (47) may be inverted to obtain the domestic firm's inverse demand function:

$$
\mathrm{p}^{1}=\theta\left(\mathrm{q}^{1}, \mathrm{p}^{2}\right), \quad \text { where } \theta_{1}=1 / \mathrm{D}_{1}^{1}<0 \quad \text { and } \quad \theta_{2}=\mathrm{D}_{2}^{1} /\left(-\mathrm{D}_{1}^{1}\right)>0 \text {. }
$$

Therefore, in the presence of an outsourcing tax $t$ and an output (export) subsidy $\sigma$, the profit of the domestic firm is

$$
\pi^{1}=\left(p^{1}+\sigma\right) q^{1}-w L_{E}-\left(w_{0}+t\right) n-w_{S} S_{E} .
$$

Using (51) in (52a),

$$
\pi^{1}=\left[f\left(q^{1}, p^{2}\right)+\sigma\right] q^{1}-w L_{E}-\left(w_{0}+t\right) n-w_{s} S_{E} .
$$

Using the production function $\mathrm{q}^{1}=\mathrm{F}\left(\mathrm{L}_{\mathrm{E}}+\mathrm{n} \delta(\mathrm{n}), \mathrm{S}_{\mathrm{E}}\right)$, we obtain

$$
\pi^{1}=\left[\theta\left(F(.), p^{2}\right)+\sigma\right] F(.)-w L_{E}-\left(w_{0}+t\right) n-w_{s} S_{E} .
$$

The first-order conditions of profit maximization for the domestic firm are

$$
\mu \mathrm{F}_{1}(.)=\mathrm{w}, \quad \mu \mathrm{F}_{1}(.)\left[\delta(\mathrm{n})+\mathrm{n} \delta^{\prime}(\mathrm{n})\right]=\mathrm{w}_{0}+\mathrm{t}, \quad \text { and } \mu \mathrm{F}_{2}(.)=\mathrm{w}_{\mathrm{s}},
$$


where $\mu=p^{1}+\sigma+q^{1} \theta_{1}($.$) .$

Notice that as in the earlier sections, (53) implies that $n=n(t, w)$. Given a minimum wage $\bar{w}$, this implies that $\mathrm{n}$ can only be affected by $\mathrm{t}$. Assuming the same structure for the import-competing competitive sector as we used in previous sections, $\mathrm{w}_{\mathrm{s}}$ is also fixed at $\overline{\mathrm{w}}_{\mathrm{s}}$. From (53) it is clear that the ratio of marginal products of unskilled and skilled domestic labor is unchanged, further implying unchanged labor intensities for both sectors. Thus,

$$
\begin{aligned}
& \mathrm{p}^{1}+\sigma+\mathrm{q}^{1} \theta_{1}\left(\mathrm{q}^{1}, \mathrm{p}^{2}\left(\mathrm{p}^{1}\right)\right)=\overline{\mathrm{w}} / \mathrm{F}_{1}\left(\bar{\lambda}_{\mathrm{E}}, 1\right) \\
& \quad \Rightarrow \mathrm{p}^{1}=\varphi\left(\mathrm{q}^{1}\right) \quad \text { and } \quad \varphi^{\prime}\left(\mathrm{q}^{1}\right)=\theta_{1} /\left(1-\theta_{2} \rho_{\mathrm{B}}^{*}\right) .
\end{aligned}
$$

Using (54) in (53)

$$
\varphi\left(\mathrm{q}^{1}\right)+\sigma+\mathrm{q}^{1} \theta_{1}\left[\mathrm{q}^{1}, \mathrm{p}^{2}\left(\varphi\left(\mathrm{q}^{1}\right)\right)\right]=\overline{\mathrm{w}}_{\mathrm{s}} / \mathrm{F}_{2}\left(\bar{\lambda}_{\mathrm{E}}, 1\right) \Rightarrow \mathrm{q}^{1}=\mathrm{q}^{1}(\sigma) .
$$

Also, using (11) we have $\mathrm{dq}^{1}=\mathrm{F}\left(\bar{\lambda}_{\mathrm{E}}, 1\right) \mathrm{dS}_{\mathrm{E}}$. National income is

$$
\mathrm{NI}=\pi^{1}-\sigma \mathrm{q}^{1}+\mathrm{w}\left(\mathrm{L}_{\mathrm{E}}+\mathrm{L}_{\mathrm{M}}\right)+\mathrm{bL}_{\mathrm{u}}+\mathrm{tn}+\mathrm{w}_{\mathrm{s}} \overline{\mathrm{S}},
$$

which can be reduced to

$$
N I=\varphi\left(q^{1}\right) q^{1}+\bar{w}_{s} S_{M}-w_{0} n+b\left(\bar{L}-L_{E}\right)+(\bar{w}-b) L_{M} .
$$

Totally differentiating (57) and simplifying, we get

$$
\begin{aligned}
\mathrm{dNI}= & {\left[\mathrm{q}^{1} \varphi^{\prime}\left(\mathrm{q}^{1}\right) \theta_{2} \rho_{\mathrm{B}}^{*}-\sigma+(\overline{\mathrm{W}}-\mathrm{b})\left(\lambda_{\mathrm{E}}-\lambda_{\mathrm{M}}\right) / \mathrm{F}\left(\lambda_{\mathrm{E}}, 1\right)\right]\left(\mathrm{dq} \mathrm{q}^{1} / \mathrm{d} \sigma\right) \mathrm{d} \sigma } \\
& +\left[\mathrm{b}\left(\delta+\mathrm{n} \delta^{\prime}\right)-\mathrm{w}_{0}\right] \mathrm{n}_{\mathrm{t}} \mathrm{dt} .
\end{aligned}
$$

The optimum outsourcing tax and the export subsidy are

$$
\mathrm{t}_{\mathrm{opt}}=\left(\mathrm{w}_{0} / \mathrm{b}\right)(\overline{\mathrm{w}}-\mathrm{b}) \quad \text { and } \quad \sigma_{\mathrm{opt}}=\mathrm{q}^{1} \mathrm{p}^{\prime}\left(\mathrm{q}^{1}\right) \theta_{2} \rho_{\mathrm{B}}^{*}+(\overline{\mathrm{w}}-\mathrm{b})\left(\lambda_{\mathrm{E}}-\lambda_{\mathrm{M}}\right) / \mathrm{F}\left(\lambda_{\mathrm{E}}, 1\right) .
$$

Therefore, the optimal policies remain qualitatively unchanged except for the profit-shifting portion $\left[\mathrm{q}^{1} \varphi^{\prime}\left(\mathrm{q}^{1}\right) \theta_{2} \rho_{\mathrm{B}}^{*}\right]$ of the optimal export subsidy. This portion is likely to be positive given that Bertrand 
reaction functions are likely to be positively sloped (i.e., $\rho_{\mathrm{B}}^{*}>0$, also see Eaton-Grossman, 1986). The effect of the labor-market distortion on optimal policy is completely unchanged compared to the Cournot case, demonstrating that our analysis is robust to the mode of oligopolistic competition.

\section{Conclusion}

To our knowledge this is the first paper that presents a general equilibrium analysis of outsourcing for oligopolistic firms. Inter-sectoral linkages that are ignored in partial equilibrium analysis are shown to be critical in determining changes in central variables like the unskilled (and skilled) wage rates, outsourcing, and national income. The labor-market results are also shown to be robust to the mode of oligopolistic competition. The models are general enough and may be adapted to address issues like the effects of dual labor markets in developing nations and second-best labor-market policies in the context of trade distortions, among others. 


\section{References}

Bhagwati, J., A. Panagariya, and T.N. Srinivasan, 2004, The muddles over outsourcing, Journal of Economic Perspectives, 18(4), 93-114.

Brander, J.A., and B.J. Spencer, 1985, Export subsidies and international market share rivalry, Journal of International Economics, 18(1-2), 83-100.

Brander, J.A., and B.J. Spencer, 1988, Unionized oligopoly and international trade policy, Journal of International Economics, 24(3-4), 217-34.

Brecher, R.A., 1974a, Minimum wage rates and the pure theory of international trade, The Quarterly Journal of Economics, 88(1), 98-116.

Brecher, R.A., 1974b, Optimal commercial policy for a minimum-wage economy, Journal of International Economics, 4, 139-149.

Eaton, J., and G.M. Grossman, 1986, Optimal trade and industrial policy under oligopoly, The Quarterly Journal of Economics, 101, 383-406. 